\title{
Dva životy, dvě kultury, dvě země
}

\section{Jana Poláková}

V rámci připomenutí „osmičkových“ výročí jsou dnes nejčastěji zmiňovány obecně známé historické skutečnosti. Vedle nich se však v těchto letech staly události, které ovlivnily podobně život české společnosti, nicméně povědomí o nich je v podstatě marginální. Před sedmdesáti lety, přesně 23. 4. 1948, přijalo tehdejší Československo v jihomoravském Mikulově první vlakový transport necelých osmi set dětí z Řecka. Pocházely ze severních horských oblastí zasažených občanskou válkou mezi zastánci monarchistické (západními zeměmi podporované) a levicové politické orientace. Po první skupině přijelo během dvou let ještě šest dalších podobných. V následujícím roce pak přicházeli také dospělí, kteří patřili v maximální míře $\mathrm{k}$ sympatizantům poražené levice.

Hlavním organizátorem pomoci utečencům byla Československo-řecká společnost, jejíž agendu o několik let později převzal Československý červený křiž. Pobyt Řeků v Československu byl zpočátku chápán oběma zúčastněnými stranami jako přechodný, ani jedna proto prvoplánově neusilovala o jejich začlenění do české majoritní společnosti. Ke konci řecké občanské války bylo zjevné, že nepůjde o dočasnou záležitost. V průběhu 50 . let 20. století byla vedle politických záležitostí řešena zaměstnanost uprchlíků, jejich bytová situace, docházelo ke slučování rodin a důraz byl kladen také na vzdělávání dětí i dospělých. K místům s největší koncentrací Řeků patřily pohraniční oblasti a města $\mathrm{s}$ potřebou pracovních sil v průmyslu, hlavně severní Morava.

Ačkoliv prŕístup státu $\mathrm{k}$ řeckým uprchlíkům byl vstřícný, nebyli během existence komunistického Československa nikdy považováni za národnostní menšinu. Důvodem bylo mimo jiné jejich setrvání u řecké státní př́íslušnosti. Většina exulantů využila po politickém převratu v Řecku v 70. letech 20. století a udělení amnestie účastníkům občanské války možnost návratu do rodné země. Zhruba tři až čtyři tisíce $\mathrm{z}$ nich zde přesto zakořenily natrvalo a položily základy dnešní řecké národnostní menšiny. V posledním sčítání lidu v roce 2011 se k ní přihlásilo 2043 občanů ČR. Ke konci roku 2017 u nás společně s nimi žilo na základě povolení $\mathrm{k}$ přechodnému nebo trvalému pobytu téměř 1500 řeckých státních př́íslušníků. Podle kvalifikovaných odhadů žije na našem území až 7000 osob považujících se za Řeky.

Př́ichod Řeků na české území a jejich život zde byl hlavním tématem výzkumu, na jehož provedení se podílel Etnografický ústav Moravského zem- 
ského muzea a Nadační fond Hellenika se sídlem v Brně. V období od června do listopadu 2017 bylo pořízeno 19 rozhovorů o celkové délce 17 hodin, zaznamenaných na zvukovou a obrazovou stopu. S ohledem na věk respondenta obsahovaly mimo jiné osobní nebo zprostředkovaný popis príchodu první (dospělí) a tzv. jedenapůlté (děti narozené mimo naše území) generace Řeků do tehdejšího Československa. Výběr respondentů směřoval ke zmapování až tř́ generací několika řeckých rodin žijících v Praze, Severomoravském a Jihomoravském kraji. Za základní pracovní metodu byla zvolena oral history. Formou semistrukturovaného rozhovoru byl zaznamenán subjektivní postoj dotazovaného, doplněný následně o prameny osobní, odborné i archivní povahy. Hlavní postup vyprávění se držel chronologického principu.

Všechny typy získaných podkladů a informací byly zpracovány do dvou stejnojmenných výstupů - filmu a výstavy „Dva životy, dvě kultury, dvě země. Řekové na českém území od 2. poloviny 20. století do současnosti“. Šestadvacetiminutový film obsahuje vedle výpovědí respondentů pořízených během výzkumu také úryvky z dobových filmů, články z dobového tisku, písemný i obrazový archivní materiál. Panelová výstava pak představuje téma o něco podrobněji. Vedle již zmíněných pramenů jsou v ní citované také výroky nebo písemné vzpomínky pamětníkủ. Návštěvník získá informace o pozadí př́íchodu řeckých obyvatel, jejich průběhu, o soužití s místní společností, udržování kulturních tradic i o návratu do původní vlasti nebo důvodech setrvání zde. Může se zároveň dozvědět o méně známých faktech, jako např̀. osudy malé skupiny členů tzv. monarchofašistické armády. Díky dlouhodobé badatelské činnosti pracovnice Moravského zemského muzea budou představeny některé dosud neznámé či nepublikované materiály.

Výstava proběhla 9. - 30. 11. 2018 v Brně, v budově Krajského úřadu Jihomoravského kraje. Po ukončení je společně s doprovodným filmem možné její zapůjčení ke kulturním a vzdělávacím účelům. Autoři výstavy nabízí také možnost přednášky na dohodnuté téma. Projekt kooperace odborného pracoviště se zájmovou organizací bude pokračovat i do budoucna. V plánu je vznik publikace obsahující přepisy pořízených rozhovorů $\mathrm{v}$ doprovodu odborného komentáře. Jedná se o výjimečnou spolupráci, jejíž výsledek je určen široké veřejnosti. Jeho cílem je seznámení se skupinou osob, která se za sedmdesát let stala běžnou součástí naší společnosti, ale přesto si stále udržuje některá kulturní specifika. Její prrítomnost si mnozí ani neuvědomují, ale po chvilce zamyšlení jistě potvrdí pravdivost slov jedné z iniciátorů a koordinátorů projektu: „Každý má svého Řeka. S někým chodil do školy, nebo bydlel na ulici, nebo podobně. Každý si na někoho vzpomene. A když nemá svého Řeka, tak je to člověk vzdělaný, který si uvědomí odkaz řecké kultury a filozofie.“ 
MEMO 2018/2

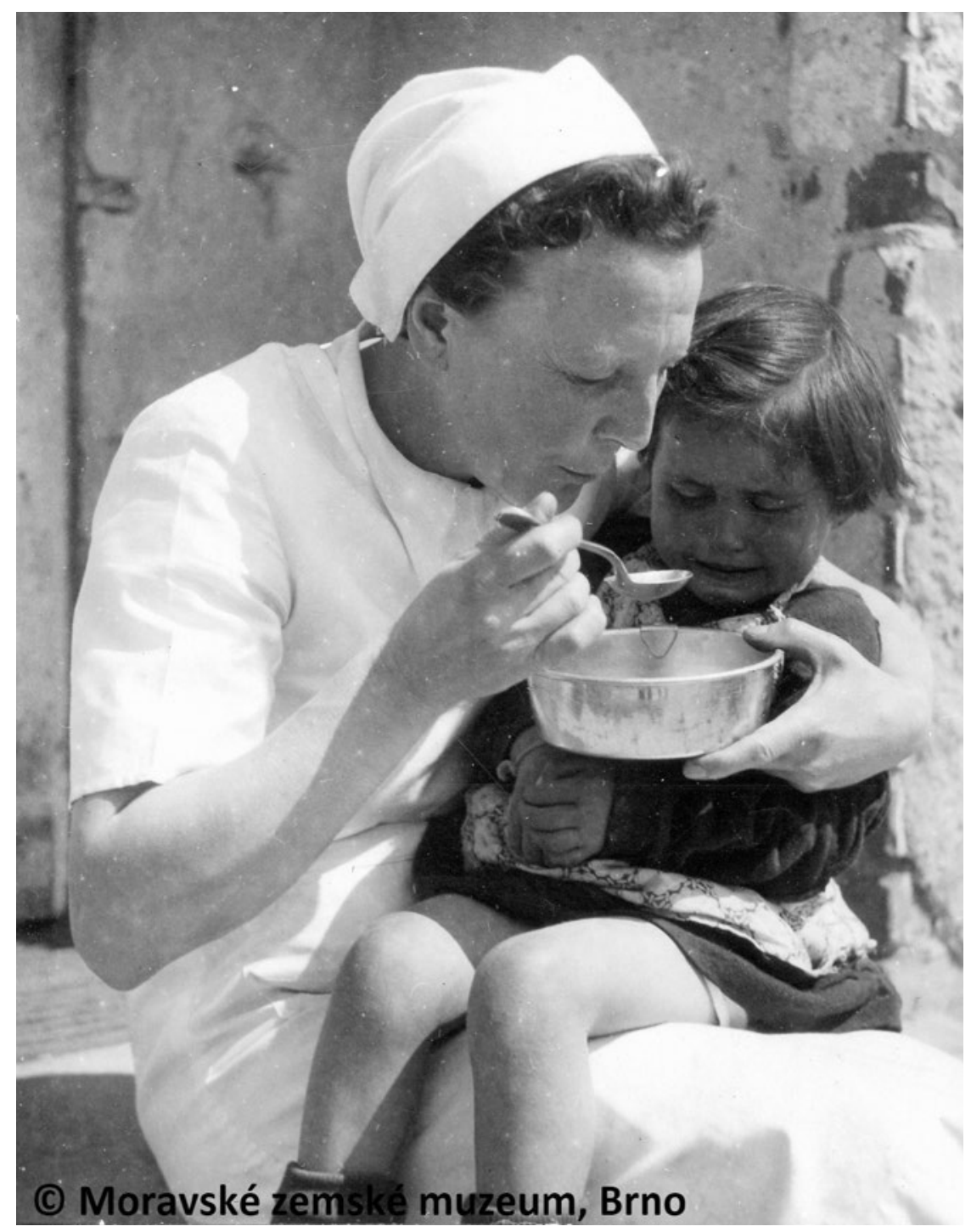

